Thomas's Mount, to the Medical Charge of the Cantonment Hospital, is confirmed. The following appointments are announced : Surgeon-Lieutenant-Colonel A. S. Reid, M.B., I.M.S., Bengal Establishment, to officiate as Medical Storekeeper at the Presidency during the absence of SurgeonMajor C. J. H. Warden on deputation. Surgeon-Captain C. W. Johnson, I.M.S., to be Civil Surgeon of the Meiktila district, in addition to his military duties. Surgeon-Lieutenant W. E. A. Armstrong, I M.S. (Madras), to officiate as Medical Officer of the Meywar Bhil Corps until further orders. Sargeon-Captain F. P. Nicholls, M.B., Army Medical Staff, has been placed in Medical Charge of the Cantonment Hospital at Trimulghery; Surgeon-Lieutenant-Colonel E. Fawcett Indian Medical Service, to the Medical Charge of the Cantonment Hospital, Secunderabad; and Surgeon-Major P. M. Carleton, on return from England, to the Medical Charge of the Station Hospital at Meiktila. Surgeon-Captain I. W. Stewart is transferred from Minbu to Akyab to be Civil Surgeon vice Surgeon-Captain C. L. Williams, whose services have been replaced at the disposal of the Government of Madras. Surgeon-Captain F. J. Dewes, I.M.S., whose services have been placed temporarily at the Chief Commissioner's disposal, has been posted as Civil Surgeon to Minbu. Surgeon-Captain M. Kelly, M.D., Army Medical Staff, has been granted sick leave to England for six months. Surgeon-Captain W. J. Buchanan, M.B., for one year. Pension service-sixth year commenced March 5th, 1893.

\section{Naval Medical Service.}

The following appointments are announced :-Surgeons : Ernest D. Minter to Pembroke, George A. Dreaper to Polyphemus, James H. Dawe to Dolphin, Edward M. Dobinson to Imogene, and Ernest E. P. Tindall to Martin.

\section{ARMY Medical Reserve of OfFICERS.}

Surgeon-Captain Alfred Chawner, 2nd Volunteer Battalion, the Sherwood Foresters (Derbyshire Regiment), to be SurgeonMajor.

\section{VoLUNTEER CORPS.}

Artillery: 2nd Durham (Seaham) Western Division Royal Artillery: Surgeon-Lieutenant-Colonel T. C. Beatty resigns his commission; also is permitted to retain his rank and to continue to wear the uniform of the Corps on his retirement.--Rifle: 1st Roxburgh and Selkirk (the Border) Surgeon-Captain J. Menzies, M.D., to be Surgeon-Major Surgeon-Major J. Menzies, M.D., resigns his commission and is permitted to retain his rank and to continue to wear the uniform of the Corps on his retirement. - 2nd Volunteer Battalion, the Queen's Own (Royal West Kent Regiment) : Surgeon-Lieutenant Mowbray Taylor is appointed Captain and Francis Croucher, M.B., to be Surgeon-Lieutenant.

\section{The Volunteer Officers' Decoration.}

The following members of the medical profession, whose names appear in the London Gazette of Tuesday, Oct. 3rd, have received the Volunteer Officers Decoration: NorthEastern District: Rifle: 1st Volunteer Battalion, the Princess of Wales's Own (Yorkshire Regiment) : Surgeon-Major Alfred Baker.-Western District: Artillery: 1st Devonshire (Western Division, Royal Artillery): Surgeon-Lieutenant-Colonel George Pigott Barton and Surgeon-Major George Pycroft, retired. Thames District: Artillery: 1st Kent (Kastern Division, Royal Artillery) : Surgeon-Major Charles Arrol, M.D.

DeATHS IN THE SeRvices.

Deputy-Surgeon-General William Nixon Armstrong, Army Medical Department, died at Lansdowne, Farquhar-road, Upper Norwood, on the 24th ult. He served with the 54th Regiment in the Indian Mutiny; was in medical charge of the expedition to Sylhet in 1857 and also of a Field Force in Oude, including attack on the Fort of Leheau in March, 1858 (medal). Previous to his retirement in 1878 he was on the staff at the Curragh. Surgeon-Lieutenant-Colonel Gilligan, I.M.S., died at Lahore on Aug. 22nd of heat apoplexy. He had just returned from a two years' furlough to England.

The Profmssorship oe Hygiente at Chatham.

Brigade-Surgeon-Lieutenant-Colonel J. Lane Notter, Professor of Hygiene in the Army Medical School, Netley, has been appointed Lecturer on Hygiene at the School of Military Engineering at Chatham. The course will be given during the month of December. The appointment was formerly held by Dr. E. A. Parkes, F.R.S., of the Army Medical School, Netley,
The Recent GazeTte OF India and Fees For Medical atrendance on Native Chreis.

We do not see what is the necessity for the publication of fresh regulations by the Government of India on the subject. of fees to medical officers for professional attendance on. native chiefs and native gentlemen of high position. If it be true, as alleged, that it was occasioned by the recent presentation of a very large fee from a wealthy and grateful patient to a very skilful medical officer, it is a general ruling based upon a particular case-a method. of procedure which is almost always open to objection. It is not very long ago that the Indian Government issued regulations on this subject of fees, to which we called attention at the time, and at first we imagined that the present. ruling was simply a re-publication of the former one. Such. does not seem to be the case, however. It appears that any fee may be offered by a native chief; but the offer must be reported by the medical officer for the consideration of the Local Government, which has authority to allow the acceptance of the fee unless it appears excessive or disproportionate to the service rendered, in which case the orders of the Government of India are necessary. That part of the order which says that the medical officer in sub. mitting his report may state, "so far as he is able consistently with his position, " the professional importance of the case and the nature and amount of the relief afforded does not appear to us to place the medical officer in a very dignified position, and it is also open to the objection that those to whom the subject is referred cannot well be the best judges of the quality and value of the professional services rendered. We cannot help asking ourselves whether such orders were really called for or whether it was expedient to issue them.

\section{Cotespondente.}

\section{"Audi alteram partem." \\ THE EPIDEMIC OF TYPHOID FEVER AT WORTHING. \\ To the Editors of THE LANCET.}

SIRS,-In a letter from Dr. Goldsmith of Worthing in the Standard of Oct. 3rd, pointing out the contamination of the water of that town by sewage, reference is again made to the bacteriological examination. It is quite true that certain samples of the water were found to be pure, and the report containing this statement has been widely quoted, but no notice, so far as I am aware, has ever been taken of my earlier report which was submitted to the mayor and corporation at the commencement of the outbreak. You will see that the bacteriological examination of the water showed filth pollution and that I condemned the water in the strongest possible language. I enclose for publication a copy of that report. I am, Sirs, yours faithfully,

King's College, London, Oct. 4th, 1893.

DGar M. Crookshank, Professor of Bacteriology.

\section{COPY OF BACTERIOLOGICAL REPORT ON THE} WORTHING WATER.

May 29th, 1893

I beg to report the results of the bacteriological examination of the samples of water received under the instruction of the sanitary committee.

These samples were examined with as little delay as possible, as a very considerable increase in the number of bacteria present in samples of water may occur if the samples be kept. for some time before the analysis is made. For the information of the committee it may be as well to describe briefly the methods used and to give some results obtained with the same methods in the examination of pure and impure water from various sources. This will enable the committee to appreciate the importance of these examinations, and I would especially lay stress upon the fact that a bacteriological analysis may. show the presence of poisonous or disease-producing bacteria. when their detection is not possible by means of a chemical analysis. The contagia of such diseases as diphtheria typhoid fever and cholera may be present in such smalk numbers that no chemical analysis would detect any contamination, and yet, as they are living oroanisms capable of increasing in a suitable environment, very few of them gain- 
ing access to the human system will produce the grave disorders with which they are associated.

The method which I have principally relied upon is as follows: I avoided shaking up the samples which would have disturbed the sludge or deposit in $B$ and $C$, so that in all cases water as clear as possible was used. One-twentieth of a cubic centimetre of each sample was added to nutrient gelatine, previously liquefied, and the water thoroughly distributed in the cultivating medium. The liquefied gelatine was then poured out upon a glass plate and rolled out into an reven layer by means of a sterilised glass rod. These plates were then transferred to sterilised glass dishes for protection from atmospheric bacteria, and kept at a temperature of about $: 20^{\circ} \mathrm{C}$. for several days. The individual bacteria in the original sample of water are thus distributed throughout the liquid gelatine and when this sets each individual bacterium is fixed at one spot and new individuals are produced by fission, giving rise to a colony, which becomes visible to the naked eye or through the aid of a pocket lens. The next step was to count the colonies by means of a special apparatus, and thus to -estimate the number of bacteria originally present in a cubic centimetre of each sample-roughly speaking about twenty -arops. I took note also of the general characters of the bacteria which were cultivated, whether the gelatine was liquefied or decomposition produced, with development of foulsmelling gases. I also prepared cultures by using Petri's dishes, substituting agar for gelatine, by which means the organisms - can be grown at the temperature of the blood without the cultivating medium being liquefied. I also studied some of the most striking micro-organisms by obtaining pure cultures in testtubes. The plates were examined on the third and fifth days; I prefer the latter for counting the colonies, as they are then more easily visible. This illustrates the one unavoidable -objection to bacteriological examination - the time which must elapse before a report can be obtained. In studying these microscopic plants we have to give time for them to grow, and the rate of growth varies with different species.

Before giving you the result of the examination of the samples of the Worthing water I will give a few illustrations taken from examinations of other waters, and the committeee will bear in mind that an excessive number of bacteria indicates an excess of organic matter, and this may have been derived from a dangerous source. Where there is such contamination we are very likely to find diseaseproducing bacteria, and, moreover, impure water is a constant source of danger, for if the contagia of infectious diseases be introduced they will retain their vitality in such water for a long period and will in some cases even multiply, whereas the same deadly organisms introduced into pure water would in a short time perish.

At Berlin 1 cubic centimetre of the water of the Spree contained when unfiltered 4400 bacteria, filtered 53. Zegeler works lake water, unfiltered 880 , filtered 44 . Wells supplied by water from deep strata contain few bacteria, unless there is contamination with surface water. Of 16 surface wells in Belgrade with a very porous subsoil there were 4500 to 5000 bacteria in $3 ; 7800$ to 15,000 bacteria in $6 ; 18,000$ to 35,000 bacteria in 6. Of 47 wells in Stettin there were less than 100 bacteria in 6 ; from 100 to 500 bacteria in 21 ; from 1000 to 18,000 bacteria in 16 . Of 13 wells in Göttingen there were less than 100 bacteria in 1 , and from 180 to 4940 in 12. In deep wells and springs the water is almost entirely free or contains very few. From an artesian well at Mainz there were 4 bacteria per cubic centimetre, at Kiel 57, and from wells at Jena 156, 51, 32 and 109 respectively. Taking various German cities, 69 per cent. of the wells contained less than 500 bacteria per cubic centimetre.

The water of sewers gives very different figures :-

Clichy . . 6,000,000 bacteria per cubic centimetre.

London. : 7,500,000

Speaking generally, water containing less than 100 bacteria to the cubic centimetre is probably from a deep source and ancontaminated by surface drainage, and therefore may be safely recommended. Water containing more than 500 is suspicious; water containing 1000 or more is presumably contaminated by sewage or surface drainage and should be rejected or filtered. The committee will also bear in mind that in typhoid fever and Asiatic cholera the excreta contain the bacteria in great numbers, and wells and streams receiving surface waters may be contaminated in varions ways. The cholera bacillus dies, as a rule, quickly in distilled. water, whilst it preserves its vitality for a long time in water of a bad quality.

Briefly, the results obtained with the Worthing water were as follows:-The three samples were labelled $A, B$ and $C$ and all examined in the way $I$ have described and six control experiments made with the water in use at King's College. The plate cultivations and cultivations in Petri's dishes of samples $B$ and $C$ contained innumerable colonies, and on the fifth day the plates were completely liquefied. The proportion of liquefying colonies was very large, and many of the bacteria produced a green colour. On raising the dish which covered the plates the odour was extremely offensive. I can only compare the plate cultures which were obtained from samples $B$ and $C$ with cultures of sewage water, or water intentionally mixed with fæcal matter in studying the bacteria of the intestines and the number of colonies present could only be estimated in millions. In sample A there were 118,000 bacteria to the cubic centimetre with some odour of putrefaction, but nothing to compare with the extremely offensive odour produced by the plate cultivations of $B$ and $C$. In the control experiments made with the water at King's College there were less than 100 bacteria to the cubic centimetre. I could not use terms too strong in condemnation of the water in samples $B$ and C. Such water, if contaminated with the contagium of typhoid fever or of Asiatic cholera would be a source of the greatest possible danger to the inhabitants, and the only reason for hesitation in suggesting that such water might astually originate typhoid fever without a previous case is the uncertainty which still surrounds the question of the exact etiology of this disease. With regard to sample $A$ the number of bacteria is far too high, containing as it does more bacteria than unfiltered Thames water in the worst month (December) and nearly as many as unfiltered Lea water in the same month. Allowing for an excess of bacteria as possibly the result of the time elapsing between the taking of the sample and the receipt and examination in London I should consider that such water should be filtered before use.

In conclusion I would point out that we can only arrive at a just conclusion by laking all the evidence into account and that the chemical and bacteriological analyses must be taken together with all other obtainable evidence, and especially that obtainable from the greatest of all tests-the effect upon the inhabitants of Worthing.

EDgar M. Crookshank,

Professor of Bacteriology and Director of the Bacteriological Department of King's College, London.

P.S.-In another report, in June, I again referred to these samples of the Worthing water as having shown "unques. tionable evidence of pollution by filth."-E. M. C.

\section{"THE REPORT OF THE SELECT COMMITTEE ON MTDWIVES' REGISTRATION." \\ To the Editors of THE LANCET.}

SiRs,-Absence from home prevented my seeing the recent numbers of THE LANCET ; but perbaps you will permit me now to point out that I have actually done what you suggest should have been my duty. Referring to my remark that I "had seen more harm done by the mal-educated student than by absolutely illiterate women," you say, in THE LANCET of Sept. 23rd: "It would have been better made in the General Medical Council or in his own college before men who might have been seized with some compunction as being responsible for defective education and as having the means of altering it." This I have actually done, and as proof beg to refer to THE LANCET of Nov. 29th, 1890, and of May 30th, 1891. I was appointed a member of the Council in 1889, and in October, 1890, on my motion, a letter was addressed by the Registrar of the Royal College of Physicians of Ireland to the General Medical Council "requesting the Council to take steps to increase the educational standard of midwifery amongst medical students," and urging that "in addition to lectures students should attend for six months a recognised lying-in hospital and attend under the proper superrision of a registered medical practitioner thirty cases of labour, instead of three, as suggested by the Council.".

A resolution founded on this letter was moved at the November meeting of the Council (1890) by Dr. Glorer and seconded by me, but on a division it was lost. At the meeting of the Council in the following May (1891) Dr. Glover and I again brought the matter forward, and $I$ then stated the facts you allude to, but was again defeated. Both I personally and my college have done all that is possible in the matter. 